\title{
The Interface Between Deforestation and Urbanization in the Brazilian Amazon
}

\author{
Julia Corrêa Côrtes \\ Roberto Donato da Silva Júnior
}

${ }^{I}$ Unicamp, Campinas, SP, Brasil.

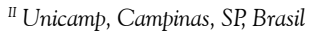

\begin{abstract}
The urban becomes fundamental in the reconciliation of environmental issues given the current global urbanization. This study aims to pursue guidelines for developing a methodological approach that enlightens the relations between deforestation and urbanization in the Amazon. Considering the intense urban transition undergoing in the region, a systematic review was conducted to understand the state of knowledge and challenges of this scope. The analysis highlighted four investigative perspectives with relevant contributions, which could be better articulated with adjustments in the analysis system, an urban conceptual reformulation, and also with variables sensitive to sociospatial dynamics. Approaches to social theory of mobility and risk have supported the design of an urban critical theory in line with the multidimensionality and transscalarity of the urban fabric socio-landscapes. By adding analytical perspectives from the spatial demography field, the study presents a theoretical-methodological framework to approach the contemporary interface between deforestation and urbanization.
\end{abstract}

Keywords: Urban fabric; land use and cover; critical social theory.

São Paulo. Vol. 24, 2021

Original Article

DOI: http://dx.doi.org/10.1590/1809-4422asoc20190182r1vu2021L1AO 


\section{Introduction}

The role played by the Amazon in the maintenance of ecological services confers a global relevance to this biome (ALENCAR et al., 2004; BECKER, 2005; RAMOS, 2001). At the national level, its hydrological dynamics influences the rainfall regime in other parts of Brazil, a process described by the theory of flying rivers (VIANA, 2011). At the global level, it assumes a preponderant role in the climate change scenario due to the carbon stock present in its vegetation cover and in the soil (KISSINGER; HEROLD; DE SY, 2012; NOBRE; SAMPAIO; SALAZAR, 2007). Considering these and other environmental and economic reasons, the Amazon awakens diverse interests and gains prominent space in global discussions on the impacts caused by human activities, with emphasis on deforestation.

Deforestation is perhaps the most relevant and complex challenge in the debate on reconciling conservation and regional development in the Amazon. With the implementation of the Action Plan for the Prevention and Control of Deforestation in the Legal Amazon (PPCDAm) by the Federal Government ${ }^{1}$, in 2004, the deforestation rate in the region significantly dropped, according to data from the System for Monitoring Deforestation in the Legal Amazon (PRODES/INPE). The main reduction occurred in the first phase of the program $(2004$ - 2008) driven by the creation of Protected Areas and Indigenous Lands. Since 2014, when deforestation reached its lowest value, a resumption of growth in annual rates has been speculated, as indicated by the PRODES/INPE data illustrated in the graph of Figure 1 - and reinforced by the monthly balance of the deforestation alert system of the Brazilian National Institute for Space Research - INPE (Deforestation Detection in Real Time - DETER).

As restraining deforestation required collective actions and involved different spheres of activity, the intensification of deforestation rates results from a wide range of geographic and historical forces and contexts (BARRETO; ARAÚJO, 2012; BRASIL, 2009). The current political-governmental scenario, some legal measures (such as the so-called "land-grabbers" law), the low general economic activity in the country, the prices of commodities (such as soybeans and beef), and the exchange rate of the Brazilian currency against the US dollar were some points suggested by Fearnside (2019) to explain the recent resumption of deforestation.

Understanding the factors and actors involved in deforestation and the ways they synergistically act requires different investigative approaches and disciplinary foundations, considering their transscalarity and interdisciplinarity (GEIST; LAMBIN, 2001; MORAN; BRONDÍZIO, 1998; TURNER; LAMBIN; REENBERG, 2007). Scientific studies tend to focus on regional narratives based on political-economic factors (CÔRTES; D'ANTONA, 2014), masking inter- and intra-regional differences as well as personal motivations (MORAN; BRONDÍZIO; BATISTELLA, 2008). The promotion of actions toward forest conservation and deforestation control requires a comprehensive look at

1 - Federal Government program that proposes actions mainly concentrated in the region of the Arc of Deforestation and that are articulated in three main thematic cores: Land and Territorial Planning, Environmental Monitoring and Control, and Promotion of Sustainable Productive Activities. 
the phenomenon, which is sensitive to sociocultural issues of the involved agents and incorporates the local perception where decisions are materialized, without disregarding the contexts structured by urbanization.

Figure 1 - Time series of annual deforestation rates in the Legal Amazon (1994 - 2019), with emphasis on the period after the PPCDAm* implementation

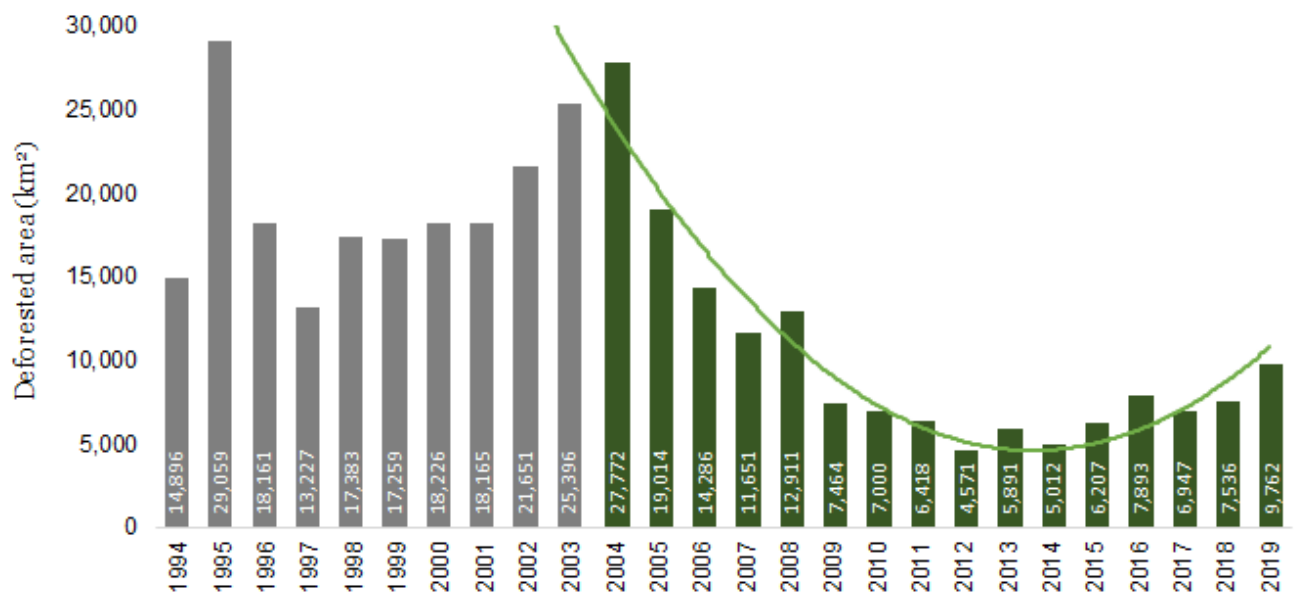

* PPCDAm - Action Plan for the Prevention and Control of Deforestation in the Legal Amazon

Source: INPE/PRODES, 2020. Prepared by the authors.

Nowadays, the urban condition is a central factor in any environmental discussion (SASSEN, 2009). Observing rural transformative processes from an autonomous conception of rurality is a lagged strategy, considering that they are socio-landscape constructions interconnected to the social and material dynamics located in urban conglomerates (CÔRTES et al., 2020; SASSEN, 2009). Despite being considered an urbanized forest (BECKER, 2013), there is little consensus on the interactions between the urbanization process and changes in land use and cover in the Amazon.

By acknowledging this gap, the objective of the study is to seek theoretical-conceptual guidelines that point to the development of a methodological approach capable of explaining the interface between urbanization and deforestation. To do so, a systematic literature review have fostered the discussion about the state of knowledge on the theme. The qualitative analysis showed the advances and agreements between the fields of study, and highlighting the challenges that originate from a still antagonistic rural-urban conception, and from few premises in the analysis system design. Based on a theoretical reflection about the redefinition of these spaces and their relational logics, a set of directions was created, which intertwines dialogues between urban studies and critical social theory, providing guidance for new empirical investigations in the field of changes in the land use and cover. 


\section{The urbanized forest: urban transition in the Amazon}

The United Nations Population Fund, the international development agency of the United Nations that deals with population issues, has reinforced that urbanization is the component of greatest influence on the development of countries today (UN, 2014). According to the theory of urban transition (SKELDON, 1990), urbanization proceeds through the gradual transition of the population from predominantly rural to urban, an intrinsic phenomenon of societies in economic development and, therefore, predicted to inexorably occur in a global way (MARTINE; MCGRANAHAN, 2013; MONTGOMERY et al., 2003).

The analysis in different historical and geographical contexts shows that urbanization intensifies over time, shortening the transition period from rural-agricultural to urbanindustrial society (ALPHAN, 2003; COHEN, 2004; MARTINE; MCGRANAHAN, 2010a; UN, 2014). Considering the specificities of each country, the world population has been mostly urban since 2007 (MARTINE; MCGRANAHAN, 2010a, 2010b). In Brazil, this transition occurred during the 1960s and, as evidenced by data from 2017, $85 \%$ of the Brazilian population lives in urban areas (PNAD, 2017). The country is recognized for an early urban transition and one of the most accelerated in the world's history (MARTINE; MCGRANAHAN, 2010a).

In the northern region of the country, the urban transition started later than the south-southeast part of Brazil. While Brazil reached $50 \%$ of total population living in urban areas over the 1960s (driven by the Southeast region), the region in which the Amazon biome is inserted became mostly urban in the late 1970s (Figure 2). In 2010, the urban population in the North region represented $73 \%$ of the total, the lowest proportion in the country alongside the Northeast region, though with the highest rate of growth of the urban population (IBGE, 2010). This panorama highlights the intensity of urbanization in the region and suggests there is still a significant path to be followed, strengthening the need for regional urban planning.

For Corrêa (1987), the urban network in the Amazon can be described according to seven moments, having the economic formations of the context as a discriminatory character. They are as follows: 1) the foundation of the city of Belém, state of Pará, in 1616 , by the Portuguese as the beginning of the defensive control of the territory; 2 ) the creation of missionary villages and the extraction of drugs from the backlands with the exploitation of indigenous labor (from 1655 to 1750); 3) the introduction of commercial agriculture and the transformation of hamlets into villages such as Aveiro and Santarém, in the state of Pará (from 1755 to 1778); 4) the economic stagnation of the region and urban life (from 1778 to 1850); 5) the economic boom of rubber and the valorization of the regional economy with the introduction of steam navigation and northeastern migration (from 1850 to 1920 ); 6) the crisis in rubber production and the consequent economic stagnation in the region (from 1920 to 1960); and 7) the redefinition of the role of the region in the territorial division of labor and its incorporation into the general process of capitalist expansion in the country (from 1960 onward). 
Figure 2. Time series of the percentage of total population living in urban areas and the annual rate growth according to the Major Regions of Brazil, 1950 - 2010
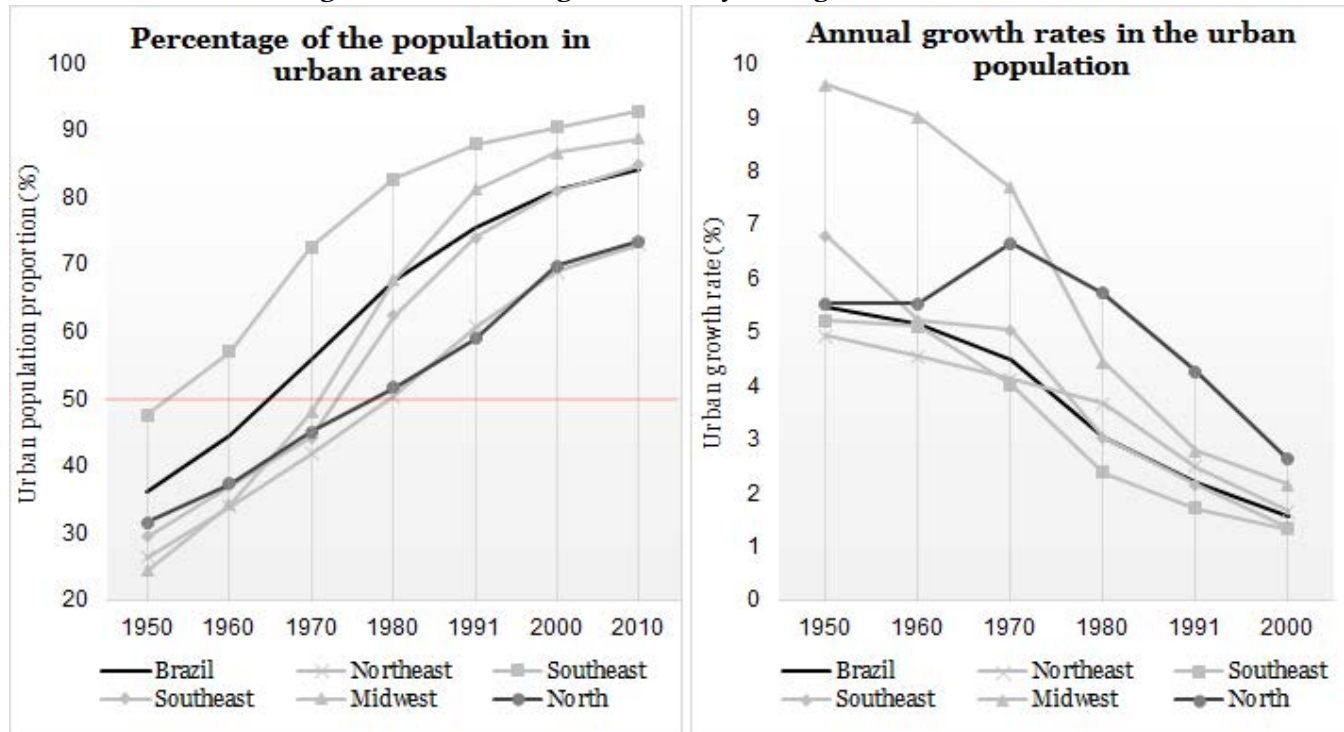

Source: Data from the Demographic Census (IBGE). Prepared by the authors.

Until 1960, urbanization was structured in a dendritic network guided by a fluvial logic, with cities strategically located for conquest and defense - referring to the colonization process. In this period, the region contained two important urban references, Manaus (state of Amazonas) and Belém, a high number of small nuclei and the absence of intermediate centers (KAMPEL; CAMARA; MONTEIRO, 2001; PEREIRA, 2006). The transition into a complex regional network occurred after 1960, followed by a change in the nature and meaning of the urban network, being, therefore, a landmark of the Amazon urbanization (BECKER, 1985, 1995; BROWDER, 2003; BROWDER; GODFREY, 1997; HOGAN; D'ANTONA; CARMO, 2008; KAMPEL; CAMARA; MONTEIRO, 2001 ).

The definitive presence of the State through a set of interventions, institutions, and ideologies shaped migration policies, attracting people mainly from the Northeast region of the country. The colonization projects were intended to promote individual plots to small producers, but also to create agricultural villages considered urban centers (MELLO, 2006) - many which later fulfilled the function of regional centers (HOGAN; D'ANTONA; CARMO, 2008; MELLO, 2006; MORAN, 1981).

Thus, the urban frontier initially promoted the dispersion of small agglomerations and their isolation from urban life in state capitals, and later, throughout the 1970s, the formation of metropolitan regions and the appearance of new population densities (CASTRO, 2006; KAMPEL; CAMARA; MONTEIRO, 2001; MELLO, 2006; PEREIRA, 2006). On the one hand, large old centers, such as Manaus and Belém, grew in terms of population volume due to the density and spreading of the urban center; on the 
other hand, small municipalities emerged in areas that previously comprised forests or isolated rural villages such as Brasil Novo and Medicilândia (BECKER, 1985; HOGAN; D'ANTONA; CARMO, 2008).

Currently, the urban structure in the Amazon is characterized by the predominance of medium-sized municipalities, though still maintaining low connectivity and dispersed distribution (PEREIRA, 2006). In a process of convergence in relation to national standards, the Amazon region is increasingly becoming an urban territory with a predominance of the urban-urban migration type (HOGAN; D'ANTONA; CARMO, 2008). Although expressive, the understanding of what urban transition means in the context of deforestation is still poorly clarified (CÔRTES; D'ANTONA, 2014; DEFRIES et al., 2010).

\section{Deforestation and urbanization: a systematic literature review}

Urban areas are still poorly addressed in studies on land use and land cover change, which contributes to the still limited understanding of the relationship between urbanization and deforestation in discussions concerning the Land Change Science field of study (MORAN, 2010; CÔRTES, D'ANTONA, 2014). In order to present the empirical state of knowledge of this scientific scope and to identify the gaps and challenges inherent in these studies, we carried out a qualitative analysis of the subject based on a systematic literature review.

The survey of scientific articles and academic studies was performed using the Google Scholar search tool, considering the time frame from 2000 to 2019. The primary selection criterion was the insertion in the Land Change Science scientific field, which resulted in the inclusion of not only studies on the relationship between urbanization and deforestation, but also others that were included in the scope of land use and cover change and which employed the "urban" term in some analytical component of its methodology. At the end, 20 articles published in indexed scientific journals, four full studies published in annals of scientific events, and two doctoral dissertations were selected, totaling 26 national and international studies.

The search engine for word search was sequential; first, the sequencing of characters "urban*" was used as the root word, alternating the set of additional words, for example, "deforestation," "forest," "Amazon," "land use"; then, the root word consisted in terms from the Land Change Science field, such as "land use" and "deforestation," having as an additional set words belonging to the field of Urban Studies such as "city," "urban center," and "urbanity" - in Portuguese and English languages. In both steps, the definition for inclusion was not restricted to the title of the article, with recurring pre-reading of the studies for assessing eligibility. Systematization of the information resulted from the directed reading of these studies focusing on the following parameters: disciplinary field, research objective, approach to the urban theme, data source, applied variables, and results. The analysis resulted in the categorization into four large study groups.

A first point observed in this exercise was the multiplicity of disciplinary fields. This finding reinforces the complexity of the dynamics of land use and cover, an essentially 
interdisciplinary phenomenon. The contribution of these fronts is enormously valuable for exposing the phenomenon under different perspectives, theoretical contributions, and research methods specific to each discipline (URIARTE; SCHNEIDER; RUDEL, 2010). However, there is little integration or dialogue between fields, and even when elements from other disciplines are employed, the hegemony in the composition of authors ultimately limits their potential for understanding or applying such concepts (CÔRTES; D'ANTONA, 2014). Moreover, there was a reduced interest in the field of Urban Studies in terms of land use and cover. When dealing with the environmental issue, these scholars generally approach urbanization from the point of view of sustainability and climate change - even though deforestation and land use are directly associated with these dimensions.

The final qualitative analysis of the 26 studies showed two major groups that differ in addressing the urban phenomenon in their research major objectives. The first group studies the effects of demographic changes on land use and cover at the property level, in which urbanization is only a secondary element in the analysis system for adjusting the tested models. Conversely, the second group addresses urbanization as the study object of the research, explicitly seeking to establish the relationship between urbanization and land use and cover in the region under analysis.

Regarding the first group, a striking feature concerns the microscale level of the analysis. These studies result from surveys with the application of questionnaires in the Pan-Amazon Region and are conducted by researchers mainly inserted in the filed of demography, with variations in their basic backgrounds. Through sociodemographic surveys, the environmental changes that occur at the level of the rural property are analyzed based on factors related to the personal and household life cycle, which, adjusted to the contextual political-economic factors, allow to approach the decision-making of individuals and their personal and family motivations.

Part of these studies aims to understand how changes in the population composition and structure in the household affect patterns of land use and cover in the property - the Household Life Cycle Model ${ }^{2}$. In order to meet the multiple dimensions that are intertwined in this system, statistical models are composed of endogenous variables (population characteristics of the household) and exogenous variables (political and economic context). One of the exogenous variables applied is the integration with the market, considering that the indicator created for this dimension is "distance from the nearest urban center." The findings are quite consistent: all the studies that applied this variable showed that the proportion of forest on the property increases the farther they are from the urban center. Other classes of land use also indicated a significant relationship: positive, with annual crops; and negative, with perennial crops and pasture (CALDAS et al., 2003; CÔRTES, 2017; GUEDES, 2010; GUEDES et al., 2011; PERZ, 2003; PERZ; WALKER; CALDAS, 2006; WALKER et al., 2002)

2 - The theoretical basis of the model is the labor $\mathrm{x}$ consumption relationship and its variation over time in response to the number of children, adults, and older people. Each stage of the family trajectory would have an availability of labor force and a demand for consumption influencing the property and type of crop cultivated on the area (WALKER et al., 2002) 
The other segment of microscale studies seeks to understand the effects of migrations on the landscape configuration of the property - for the purpose of this research, the results presented were related to the rural-urban migration type. In these investigative approaches, urbanization is a narrative that gives rise to personal and family motivations; hence, it is treated as an area of population absorption where individuals or groups are enticed by the set of factors of migration attractiveness such as the labor market, access to education and services, among others.

A study on the Peruvian Amazon showed that female migration to urban centers would be associated with the reduction of forest on the property, whereas for men this type of migration would be related to the expansion of pasture (BARBIERI; CARR, 2004). In the Brazilian Amazon, in turn, the study found a significant relationship between ruralurban migration and the high-value production system such as perennial crops and pasture (VANWEY; GUEDES; D'ANTONA, 2011). In both studies, there are hypotheses regarding the forces of causality and their explanations, but which reinforce the existence of a relationship between migration decisions and landscape patterns of the property. Other studies, which have a greater interface with the Natural Sciences field, investigate the capacity for forest regeneration after abandoning the property or activities at the expense of the migration of the family group to urban centers. Having as theoretical framework the Forest Transition Theory ${ }^{3}$, forest regeneration was not associated with rural-urban migration, but rather with the sociodemographic and environmental characteristics of the property itself (BARBIERI; CARR; BILSBORROW, 2009; GRAY; BILSBORROW, 2014; PERZ; SKOLE, 2003; RUDEL et al., 2005; RUDEL; BATES; MACHINGUIASHI, 2002).

Regarding the second type of investigative approach, which seeks to understand the effects of urbanization on forests, the data sources are secondary and aggregated at the municipal, regional, or continental level. With greater interface with Natural Sciences, correlational studies work on the association between deforestation and some synthetic indicators of urbanization such as percentage of total population living in urban areas and annual growth rate of population. The findings are not general due to variations in the regional context, in addition to being statistically weak, which demonstrates the imminent complexity of this relationship (ALPHAN, 2003; DAL'ASTA et al., 2012; DEFRIES et al., 2010; DENG et al., 2009; HIRYE; DAL'ASTA; MOREIRA, 2013; JORGENSON; BURNS, 2007; KALNAY; CAI, 2003).

DeFries and colleagues (2010) analyzed the effect of the growth of the urban population on continental blocks of developing countries. Although they found a positive association between the rate of urban population growth and annual deforestation, there is significant variation between the regions under analysis. Specifically, in Latin American countries, the association shows that the group of countries that grew in the range of 2 to $3.5 \%$ per year had a variation of $85 \%$ in the annual deforestation values.

3- The theory predicts the recovery of forest cover as societies undergo an economic development characterized by industrialization and urbanization - an economic transition based on the primary sector (extraction, agriculture, and mining) to the industrial sector, with a predominance of the service sector (RUDEL et al., 2005). 
In the conclusive discussion, they suggest that deforestation would be more associated with the demands for agriculture in the urban space and international markets than with dynamics of the urban population.

Particularly for the Brazilian Amazon, an interdisciplinary study confirmed that the relationship between deforestation and urbanization is not well established (KAMPEL; CAMARA; MONTEIRO, 2001). Deforestation analysis of the municipalities of the Sustainable Forests District of BR-1634 showed that urban dynamics directly reflects in deforestation rates, but considering the heterogeneity of the study area, it is not possible to establish a causal relationship (DAL'ASTA et al., 2012). Seeking space-time patterns of urbanization and deforestation in the state of Pará, a multiscale study reaffirmed the complexity of establishing conclusive relationships between these two phenomena (RIBEIRO et al., 2019).

While correlational studies with emphasis on aggregate indicators seek the causal relationship between urbanization and deforestation, geospatial studies use computational tools to analyze the spatial dynamics of urban sprawl, therefore, focusing on the physical attributes of the urban space characterization. In the remote sensing community, most urban approaches focus on a discussion of urban planning, abstaining from the debate on deforestation itself (MORAN, 2010). One of the points brought up for discussion is the finding that urban areas advance in priority areas for food production (ALPHAN, 2003; DENG et al., 2009; HEROLD; GOLDSTEIN; CLARKE, 2003; TANG; WANG; YAO, 2007). There is an association between increasing the urban area and reducing the areas of agriculture and pasture in its surroundings (HEROLD; GOLDSTEIN; CLARKE, 2003).

In the Brazilian Amazon, geospatial studies reinforce that urban sprawl does not have a significant effect on forest cover - but rather on other land uses. In Altamira, a municipality in the state of Pará, urban sprawl promoted forest fragmentation and defined the spatial pattern of the remnants along the highways. In Santarém, another city in the state of Pará, where urbanization is more consolidated and old, the increase in the urban area occurred due to the appearance of population densities associated with the expansion of soy in other locations of the municipality - due to the internal spatial rearrangement of the population (CÔRTES, 2012; DAL'ASTA et al., 2013; HIRYE; DAL'ASTA; MOREIRA, 2013). Another analysis carried out in the western region of Pará reinforced that the proportion of forest converted to an urban area is low, and that the expansion of urbanization mainly occurs in pasture areas (CÔRTES, 2017).

Figure 3 summarizes how the urban is treated in the theoretical and analytical components of the studies considered in the systematic review. Geospatial studies are important for highlighting the urban as a class of land use, therefore, placing urbanization also as a product in the system of land use and cover change. Similarly, such studies show that the advancement of this class does not explain deforestation, considering that urbanization is mainly advancing in areas already deforested. These findings demon-

4 - Geo-economic and social complex determined in 2006 by the Federal Government with the purpose of implementing public policies to encourage development integrated with forest-based activity. The area, located in the west of the State of Pará, covers 190 thousand $\mathrm{km}^{2}$, fully or partially comprising 13 municipalities. 
strated how the relationship between the two phenomena is complex and impractical to understand by the causal link. Hence the difficulty in obtaining satisfactory results in correlational studies, which seek to answer how the population dynamics of urbanization promotes deforestation, instead of conceiving them as resulting from a single demographic panorama, sharing the same factors and processes.

\section{Figure 3. Analysis of the systematic review of studies on urbaniza- tion in the context of Land Change Science, highlighting the ur- ban components of the researches and its findings.}

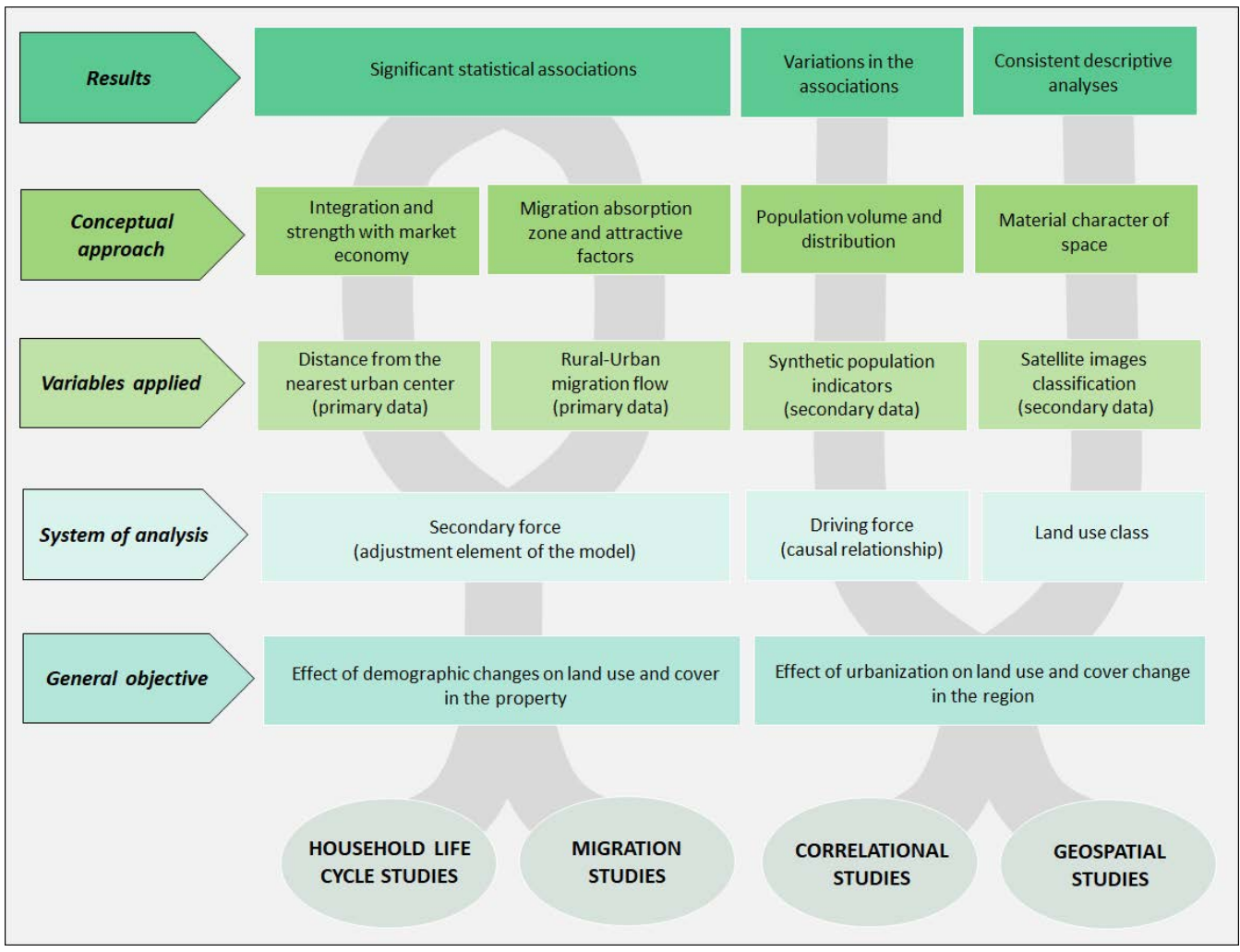

Source: Prepared by the authors, 2021.

The immediate and majority causes ${ }^{5}$ of deforestation are related to agricultural activities - and not to the increase in the urban class. The interface between urbanization and deforestation comprises this plan, in such a way that the degree of connection with the urban space is the guiding element in the expansion of agricultural activities - the type of agricultural crop, the cultivated area, the intensity of development. Studies of the family life cycle prove that this association occurs in a spatial manner, noting that the 
proximity of the rural property to the urban center reduces the forest area and increases the agricultural parcels. In turn, migration studies complement this scenario by explaining how these flows of information, capital, and material occur. This panorama suggests that the urban space has been spreading in rural areas through a broad and flexible urbanization process capable of perpetuating values and practices, with the migration flows of the population as the connecting thread.

From this perspective, the urban space ceases to be an abstract agglomeration of people in a delimited territory in order to be understood as a referential space of social and material circulation that connects ruralities in urban contexts in a single socio-landscape plan. Concerning deforestation, urbanization acts by spreading the underlying factors ${ }^{6}$, reproducing driving forces that synergistically act in decision-making and, subsequently, in the materialization of action, which in the medium- to long-term may become an urban class of land use. The connections and dynamisms of this integral fabric of urbanities are managed by population mobility and social ties, thus highlighting the importance of the socio-spatial dimension of urbanization in the context of land use and cover change.

The systematic literature review highlighted the contribution of the investigative approaches and identified three main methodological weaknesses. As for the analysis system, urbanization and deforestation are treated based on the cause-and-effect relationship, which seems to be inconsistent considering that the urban space is both a driving force and a product of the land use and cover change. Concerning urban-reference variables, data and indicators used in the studies are expressions that exclude spaces, reproducing the antagonistic view of the rural and the urban spaces. Finally, as for the conceptual context of urbanization, they are descriptions that reproduce the urban space in a one-dimensional way, emphasizing the political-economic aspects or the physical attributes of the space. In order to face these problems, we proposed to revisit classical and contemporary theoretical foundations about the production of urban space in order to support a reconstruction of urbanization as an object of empirical analysis.

\section{Theoretical and methodological reflections: urban space as an object of analysis}

The theoretical framework of the Urban Transition offers numerous advantages for measuring urbanization due to the ease of calculation and its comparability in time and space. The analyses are based on the population size of the municipalities, the urban population growth, and the percentage of total population living in urban areas, providing a valuable panorama to understand urban evolution, the differentials between regions, and to design scenarios within the scope of the urban transition (MARTINE; MCGRANAHAN, 2014). However, its analytical instruments consider the population in a one-dimensional way and are based on zoning defined by administrative requirements.

6 - In the analysis system of the Land Change Science field, the underlying factors that operate at different scales are the contextual forces that determine the direction and intensity of land use (GEIST; LAMBIN, 2001). 
Thus, the conception of urban space becomes a derivation of political and economic interests.

In Brazil, urban perimeters are defined by municipal laws and singular parameters. The demarcation of these spaces are fiscal instruments that are guided by political-administrative issues aiming, for instance, at determining property tax rates and parameters for building construction (MOURA; OLIVEIRA; PEGG, 2018). These criteria reduce urban and rural to territorial adjectives (ENDLICH, 2006) and simplify the multidimensionality of the phenomenon by adopting only macro-structural elements - denying other aspects of the urban space (CÔRTES, 2017). This construction, in addition to being artificial, fosters the antagonistic perception of rural versus urban, reinforcing the lagged perception between rural-countryside and urban-city (CÔRTES et al., 2020). The criticisms against this dichotomous model are vast and from different disciplinary fields, with broad scientific consensus of its limitation in representing the complexity of spaces (CAIADO; SANTOS, 2003; CASTRO, 2006; CHAMPION; HUGO, 2003; SILVA, 2003; WANDERLEY, 2000; UNFPA, 2007).

The production of urban space results from social processes, from forms of social and economic organization, and different cultural patterns. The concepts, rural and urban, carry meanings that go beyond a spatial differentiation of the population, they indicate distinct ways of life intertwined by identity relations with space ("the place where one lives") and with the broader spheres of society ("the place where one sees and lives the world") (LEFEBVRE, 1999; WIRTH, 1997). The representation of the urban concept expresses a particular way of using space and social life (KAYSER, 1990) and, therefore, the urban space is not uniform due to the different possibilities of interactions, choices, contexts, and intensities. Nor is it a fixed piece, well delimited and with constant typologies, but rather a space that is constantly moving, in continuous transformation (MOURA; OLIVEIRA; PÊGO, 2018).

The process of urbanization is caused by a set of vectors that condition a transitional zone between the urban and the rural with physical and social transformation - dissolving the clarity of its limits (SPOSITO, 2006). From the combination of material morphology (in terms of the city) and social morphology (in terms of the urban), emerges a new sociospatial configuration of the population (LEFEBVRE, 1999). Thus, the concepts of "rural" and "urban" are merged in a process of convergence of lifestyles, which marks a gradual passage, without rupture, but rather continuous (CHAMPION; HUGO, 2003; WANDERLEY, 2000). This idea is also expressed in the concept of urban-rural continuum, in which the urban pole assumes the role of dissipating values and practices, integrating and connecting the extremes through a scale of intensities instead of contrasts (MARQUES, 2002; WANDERLEY, 2003).

The distinction between rural and urban spaces must not be eliminated, but their functions and content are no longer contradictory, but rather constituents of an urban fabric (LEFEBVRE, 1999). Hence, the urban space takes on an extensive character, resulting from the explosion/implosion dynamics of the city - concerning itself and its immediate surroundings, though also distant (BRENNER; SCHMID, 2015; MONTE-MÓR, 2005). 
Urbanization goes beyond cities, spreading in networks that virtually penetrate spaces and constituting the urban fabric (BRENNER; SCHMID, 2015; MONTE-MÓR, 1994). The so-called extended urbanization (MONTE-MÓR, 1994) enables a productive return to debate on urbanization that transcends the dichotomous perspective and resumes the relevance of the spatial component in urban studies (SILVA; MONTE-MÓR, 2016)

From the perspective of extended urbanization, the urban space emerges as a synthesis of both, rural and urban, redefined by the new determinations of society in the global era, of fast and networked information, of compressed space/time (MONTE-MÓR, 2005). There is no linear and general urbanization trajectory, each stage corresponds instead to a specificity of the whole process. (MOURA; OLIVEIRA; PÊGO, 2018). From this perspective, urbanization is not a phenomenon of spatial and social homogenization, but a process that triggers new and distinct urban contexts (CÔRTES et al., 2020; MARQUES, 2002; WANDERLEY, 2000). These perceptions reinforce that urbanization is expressively complex and uneven (SANTOS, 2012), with no partial determinism or disciplinary knowledge that exhaust its definition, the urban context is at the same time historical, demographic, geographical, economic, sociological, psychological, semiological (LEFEBVRE, 1999).

In this sense, it is necessary to create a new framework for understanding the relationship between urbanization and deforestation. This scope also includes a reabsorption of modern theoretical and social guidelines, in order to achieve methodological approaches that are appropriate to the challenge. From the theoretical-conceptual point of view of the urban discussion, we propose to work on the articulation between urban studies with critical social theory by developing a critical urban theory, as suggested by Brenner (2009). The urban-rural space must be understood under the relation between risk and mobility of the contemporary society, considering that the multidimensional processes for effecting globalization have started to interconnect and rule social dynamics due to the complex socio-material conditions situated based on urban conglomerates (SASSEN, 2009).

From this perspective, both the different dimensions of mobility (URRY, 2012) exercised in global dynamics (time-space compression, conformation of transnational policies, economic flows, interconnected material structures, among others), as well as the production, recognition and treatment of contemporary risks (BECK, 2011), are linked to urban socio-spatial flows. Therefore, when seeking to elucidate the relationship between urbanization and deforestation within the Amazon context, it would be necessary to think and measure the contexts of urbanities associated with the local processes that combine and materialize the concrete expressions of urban production. Considering also that they are connected not only to the broad dynamics of urbanization, but also to the degree of articulation of these dynamics with globalizing forces.

\section{Conclusions}

The relevance of clarifying the relationship between urbanization and change land use and cover change in the Amazon occurs in a moment of resumption of deforestation rates under a regional scenario of intense urbanization. The systematic literature review 
regarding this subject showed the different disciplinary efforts, the scope of investigative inquiries, and the varied methodological approaches conducted in recent years. There are important contributions and progress in the knowledge of this topic that manages to elucidate certain processes. Although there is still a weak integration between the study groups and a limited capacity to generalize the findings, leading to the need for new guidelines for full understanding of the interface between urbanization and deforestation.

The analyzed studies showed that urban sprawl mainly occurs in areas already deforested, specifically in crop areas. Not being an immediate cause of change in forest cover, hence having no causal link, urbanization is at the same time a class of land use and a driving force of underlying factors that shape decision-making. This involves creating a multiscale dynamics that are structured in a cyclical and retroactive system. Urban driving forces are somehow guided by a spatial relationship, decreasing the intensity and impact with the distance from urban centers. When that expansiveness is laid out, it is clear that the effect of urbanization is not limited to the urban center. The urban values and practices are propagated in rural spaces through population flows, establishing virtual bridges in the rural-urban spectra and promoting the circulation of capital, material, knowledge and cultural aspects.

The exercise of establishing a dialogue and developing an integrated panorama from the analyzed results exposed the complexity of the theme. We identified three main methodological efforts necessary to advance this scope, namely the reformulation of the analysis system as the bottom of the investigative process, the conceptual re-signification of the urban space, and the adoption of variables sensitive to socio-spatial processes. The theoretical framework for facing these challenges was proposed based on the articulation of urban studies with critical social theory aiming at developing a critical urban theory.

Critical urban theory equates the distinction between the real and the possible, guaranteeing epistemological reflexivity by shaping a transdisciplinary theory guided by specific historical conditions (BRENNER, 2009; BRENNER; SCHMID, 2015). Based on approaches from the social theory of mobility and risk (BECK, 2011; URRY, 2012), the urbanization process is conceived as an articulation between global and local elements, which are composed of a set of redefining components of the urban-rural logic of these scale connections. In this theoretical framework, five fundamental propositions were presented to reason on the methodological guidelines capable of sustaining the relations between deforestation and urbanization in the contemporary Amazon.

Firstly, the refusal of any and every approach that considers "urban" and "rural" concepts with autonomous socio-spatial dimensions or in a dichotomous perspective. Secondly, to think about the problem of deforestation under a single socio-landscape configuration articulated between ruralities and urbanities - the constitution of the urban fabric. Thirdly, the urban transition framework must continue as a conceptual element, though reconsidering its linear vector sense (from rural to urban) in order to make room for multivectoriality - in the sense of conceiving mobility as susceptible to dynamics of translocality between urban and rural spaces. In this sense, fourthly, an explanatory deepening that seeks a multidimensional and cross-scale character of research in the socially 
established options between deforestation and conservation. In other words, taking into account the local processes of stimulus and responses to the risks and vulnerabilities provided by the dynamics of deforestation. And finally, fifthly, this articulation must be put into perspective from the set of economic, technological, and national and global political forces that these socio-landscape configurations present.

From these theoretical backgrounds emerge the analytical challenges to become feasible the empirical approach of the urbanization and deforestation relationship. Recognizing that the urban fabric is determined by a spatial restructuring and enabled by the processes of population mobility, one resorts to the incursions into Space Demography (VOSS, 2007; VOSS; WHITE; HAMMER, 2006; WACHTER, 2005) to consolidate an adequate research method with the questions and challenges presented in this article. When considering population mobility as a complex social phenomenon that goes beyond physical and economic dimensions to involve cultural, affective, imaginary, and individual dimensions (URRY, 2007), looking at spatial configurations of the population becomes a multidimensional perspective of the urban phenomenon. Thus, the approach involving the socio-spatial dimension can be a promising methodological strategy for the analytical framework, fully supporting the theoretical foundations of the critical urban theory.

\section{Acknowledgements}

The authors would like to thank the support of the Coordination for the Improvement of Higher Education Personnel (CAPES) in the development of this study, by granting a postdoctoral research fellowship.

The authors thank Espaço da Escrita - Pró Reitoria de Pesquisa - UNICAMP - for the language services provided.

\section{References}

ALENCAR, A. et al. Desmatamento na Amazônia: indo além da emergência crônica. Manaus: IPAM, 2004.

ALPHAN, H. Land-use Change and Urbanization of Adana, Turkey. Land Degradation \& Development, v. 14, n. September, p. 575-586, 2003.

BARBIERI, A. F.; CARR, D. L. Gender-specific out-migration, deforestation and urbanization in the Ecuadorian Amazon. Global and Planetary Change, v. 47, n. 2, p. 99-110, 1 jul. 2004.

BARBIERI, A. F.; CARR, D. L.; BILSBORROW, R. E. Migration Within the Frontier: The Second Generation Colonization in the Ecuadorian Amazon. Population Research and Policy Review , v. 28, n. 3, p. 291-320, 2009.

BARRETO, P.; ARAÚJO, E. O Brasil atingirá sua meta de redução do desmatamento? Belém: 
Instituto do Homem e Meio Ambiente da Amazônia, 2012.

BECK, U. Sociedade de risco: rumo a uma outra modernidade. São Paulo: Editora 34, 2011.

BECKER, B. Fronteira e urbanização repensadas. Revista Brasileira de Geografia, Rio de Janeiro, n. 3/4, p. 357-372, 1985.

BECKER, B.K. Undoing myths: The Amazon - An Urbanized Forest. In: Man and Biosphere Series; Sachs, G.M.C.I. Ed. Brazilian Perspectives on Sustainable Development of the Amazon Region. Paris: UNESCO e Pathernon Publish Group Limited, 1995. p. 53-89.

BECKER, B. Revisão das políticas de ocupação da Amazônia: é possível identificar modelos para projetar cenários? Parcerias estratégicas, Brasília, v. 6, n. 12, p. 135-159, 2001.

BECKER, B. Geopolítica da Amazônia. Estudos Avançados, São Paulo, v. 19, n. 53, p. 71-86, abr. 2005.

BECKER, B. A Urbe Amazônida. Rio de Janeiro: Garamond, 2013.

BRASIL. Plano de ação para prevenção e o controle do desmatamento na Amazônia Legal $2^{\text {a }}$ fase. Brasília: Ministério do Meio Ambiente, 2009.

BRENNER, N. What is critical urban theory? City, v. 13, n. 2-3, p. 198-207, 2009.

BRENNER, N.; SCHMID, C. Towards a new epistemology of the urban? City, n. 1, p. 151-182, 2015.

BROWDER, J. O. The urban-rural interface: Urbanization and tropical forest cover change. Urban Ecosystems, v. 6, p. 21-41, 2003.

BROWDER, J. O.; GODFREY, B. J. Rainforest cities: urbanization, development and globalization of the Brazilian Amazon. New York: Columbia University Press, 1997.

CAIADO, A. S. C.; SANTOS, S. M. M. Fim da dicotomia rural-urbano? Um olhar sobre os processos socioespaciais. São Paulo em Perspectiva, São Paulo, v.17, n.3-4, p. 115-124, 2003.

CALDAS, M. M. et al. Ciclo de vida da família e desmatamento na Amazônia: combinando informações de sensoriamento remoto com dados primários. Revista Brasileira de Economia, São Paulo, v. 57, n. 4, p. 683-711, 2003.

CASTRO, E. Prefácio. In: CARDOSO, A. C. (Ed.). O rural e o urbano na Amazônia: diferentes olhares em perspectivas. Belém: EDUFPA, 2006. p. 215.

CHAMPION, T.; HUGO, G. Introduction: Moving beyond the Urban-Rural Dichotomy. In: CHAMPION, T.; HUGO, G. (Eds.). New Forms of Urbanization: Beyond the Urban-Rural Dichotomy. New York: Routledge, 2003. p. 3-24.

COHEN, B. Urban Growth in Developing Countries: A Review of Current Trends and a Caution 
Regarding Existing Forecasts. World Development, v. 32, n. 1, p. 23-51, 2004.

CORRÊA, R. L. A periodização da rede urbana da Amazônia. Revista Brasileira de Geografia, Rio de Janeiro, v. 49, n. 3, p. 39-68, 1987.

CÔRTES, J. C. Mobilidade e redistribuição populacional em Santarém, Pará: recente reconfiguração do meio rural na Amazônia. 2012. Dissertação (Mestrado em Demografia) - Instituto de Filosofia e Ciências Humanas, Universidade Estadual de Campinas (Unicamp), Campinas, 2012.

CÔRTES, J. C. Ciclo de vida familiar e distribuição populacional na dinâmica do desmatamento e uso da terra na Amazônia paraense. 2017. Tese (Doutorado em Demografia) - Instituto de Filosofia e Ciências Humanas, Universidade Estadual de Campinas (Unicamp), Campinas, 2017.

CÔRTES, J. C.; D'ANTONA, Á. O. Dinâmicas no uso e cobertura da terra - perspectivas e desafios da Demografia. Revista Brasileira de Estudos de População, Belo Horizonte, v. 31, n. 1, p. 191-210, 2014.

DAL'ASTA, A. P. et al. Evolução recente da população urbana comparada à evolução do desmatamento nos municípios do Distrito Florestal Sustentável da BR-163. In: XVIII Encontro Nacional de Estudos Populacionais, 2012, Aguas de Lindóia.. Anais...Águas de Lindóia: ABEP, 2012.

DAL'ASTA, A. P. et al. Evolução do arranjo espacial urbano e das terras agrícolas no entorno de Santarém (Pará) no período de 1990 a 2010: Uma análise integrada baseada em sensoriamento remoto e espaços celulares. In: XVI Simpósio Brasileiro de Sensoriamento Remoto, 2013, Foz do Iguaçu. Anais...Foz do Iguaçu: INPE, 2013.

DEFRIES, R. S. et al. Deforestation driven by urban population growth and agricultural trade in the twenty-first century. Nature Geoscience, v. 3, n. 3, p. 178-181, 2010.

DENG, J. S. et al. Spatio-temporal dynamics and evolution of land use change and landscape pattern in response to rapid urbanization. Landscape and Urban Planning, v. 92, n. 3-4, p. 187-198, 2009.

ENDLICH, A. M. Perspectivas sobre o urbano e o rural. In: SPOSITO, M.; WHITACKER, A. (Eds.). Cidade e Campo: relações entre urbano e rural. São Paulo: Expressão Popular, 2006. p. 11-31.

FEARNSIDE, P. M. Os números do desmatamento são reais apesar da negação do presidente Bolsonaro. Amazônia Real, Manaus, 02 ago. 2019, Disponível em: < https://amazoniareal.com.br/ os-numeros-do-desmatamento-sao-reais-apesar-da-negacao-do-presidente-bolsonaro/>. Acesso em: 15 ago. 2019.

GEIST, H. J.; LAMBIN, E. F. What drives tropical deforestation? A meta analysis of proximate and underlying causes of deforestation based on subnational case study evidence. Louvain-la-Neuve: LUCC Report Series, v.4, p.116, 2001. 
GRAY, C. L.; BILSBORROW, R. E. Land use policy consequences of out-migration for land use in rural Ecuador. Land Use Policy, v. 36, p. 182-191, 2014.

GUEDES, G. R. Ciclo de vida domiciliar , ciclo do lote e mudança no uso da terra na Amazônia Rural Brasileira - um estudo de caso para Altamira , Pará. 2010. Tese (Doutorado em Demografia) - Faculdade de Ciências Econômicas, Universidade Federal de Minas Gerais (UFMG), Belo Horizonte, 2010.

GUEDES, G. R. et al. Ciclo de vida domiciliar, ciclo do lote e mudança no uso da terra na Amazônia brasileira: revisão crítica da literatura. Revista Brasileira de Estudos de População, Belo Horizonte, v. 28, n. 1, p. 231-240, 2011.

HEROLD, M.; GOLDSTEIN, N. C.; CLARKE, K. C. The spatiotemporal form of urban growth: measurement, analysis and modeling. Remote Sensing of Environment, v. 86, n. 3, p. 286-302, 2003.

HIRYE, M. C. DE M.; DAL'ASTA, A. P.; MOREIRA, M. A. Análise da cobertura da terra no entorno da sede municipal de Altamira e de Santarem, no período de 1990 a 2010, através de imagens TM/Landsat. In: XVI Simpósio Brasileiro de Sensoriamento Remoto, 2013, Foz do Iguaçu. Anais...Foz do Iguaçu: INPE, 2013.

HOGAN, D. J.; D’ANTONA, Á. O.; CARMO, R. DO. Dinâmica demográfica recente da Amazônia. In: BATISTELLA, M.; MORAN, E. F.; ALVES, D. (Eds.). Amazônia natureza: sociedade em transformação. São Paulo: Edusp, 2008. p. 71-116.

IBGE - INSTITUTO BRASILEIRO DE GEOGRAFIA E ESTATÍSTICA (IBGE). Base de informações do Censo Demográfico 2010. Rio de Janeiro,, 2010.

IBGE - INSTITUTO BRASILEIRO DE GEOGRAFIA E ESTATÍSTICA (IBGE). Base de informações da Pesquisa Nacional por Amostra de Domicílio (PNAD) 2017. Rio de Janeiro,, 2010.

JORGENSON, A. K.; BURNS, T. J. Effects of Rural and Urban Population Dynamics and National Development on Deforestation in Less-Developed Countries, 1990-2000. Sociological Inquiry, v. 77, n. 3, p. 460-482, 2007.

KALNAY, E.; CAI, M. Impact of urbanization and land-use change on climate. Nature, v. 423, p. 528-531, 2003.

KAMPEL, S. A.; CAMARA, G.; MONTEIRO, A. M. V. Análise espacial do processo de urbanização na Amazônia. Relatório Técnico Instituto Nacional de Pesquisas Espaciais, São José dos Campos: INPE, v.15, 2001.

KAYSER, B. La renaissance rurale. Sociologie des campagnes du monde occidental. Paris: A. Colin, 1990.

KISSINGER, G.; HEROLD, M.; DE SY, V. Drivers of deforestation and forest degradation. A synthesis report for REDD+ Policymakers, v. 48, Vancouver: Lexame Consulting, 2012. 
LEFEBVRE, H. A revolução urbana. Belo Horizonte: UFMG, 1999.

MARQUES, M. I. M. O conceito de espaço rural em questão. Terra Livre, São Paulo, v. 18, n. 19, p. 95-112, 2002.

MARTINE, G.; MCGRANAHAN, G. Brazil's early urban transition: what can it teach urbanizing countries? Londres: IIED, 2010a.

MARTINE, G.; MCGRANAHAN, G. A transição urbana brasileira: trajetória, dificuldades e lições aprendidas. In: BAENINGER, R (Org). População e Cidades: subsídios para o planejamento e para as políticas sociais. Campinas e Brasília: NEPO e UFNPA, 2010b.

MARTINE, G.; MCGRANAHAN, G. The legacy of inequality and negligence in Brazil's unfinished urban transition: lessons for other developing regions. International Journal of Urban Sustainable Development, v. 5, n. 1, p. 7-24, 2013.

MARTINE, G.; MCGRANAHAN, G. Brazil's negligent urban transition and its legacy of divided cities. In: MCGRANAHAN, G.; MARTINE, G. (Eds.). Urban Growth in Emerging Economies: Lessons from the BRICS. New York: Routledge, 2014. p. 15-54.

MELLO, N. Políticas territoriais da Amazônia. São Paulo: Editora Annablume, 2006.

MONTE-MÓR, R. L. O que é o urbano no mundo contemporâneo. Cadernos de Saúde Pública, Rio de Janeiro, v.21, n.3, p.942-948, 2005.

MONTE-MÓR, R. L. D. M. Urbanização extensiva e lógicas de povoamento: um olhar ambiental. In: SANTOS, M.; SOUZA, M. A. DE; SILVEIRA, M. L. (Eds.). Território, globalização e fragmentação. São Paulo: Hucitec/Anpur, 1994, p.169-181.

MONTGOMERY, M. R. et al. Cities Transformed : Demographic Change and Its Implications in the Developing World. Washigton DC: National Academics Press, 2003.

MORAN, E. F. Environmental social science: human-environment interactions and sustainability. New Jersey: John Wiley \& Sons, 2010.

MORAN, E.F. Developing the Amazon. Indiana: Indiana University Press, 1981.

MORAN, E. F.; BRONDÍZIO, E. S. Land use after deforestation in Amazon. In: LIVERMAN, D.; RINDUFUSS, R.; STERN, P. (Eds.). People and Pixel: Liking Remote Sensing and Social Science. Washigton: National Academics Press, 1998. p. 94-120.

MORAN, E. F.; BRONDÍZIO, E. S.; BATISTELLA, M. Trajetórias de desmatamento e uso da terra na Amazônia Brasileira: uma análise multiescalar. In: BATISTELLA, M.; MORAN, E.; ALVES, D. (Eds.). Amazônia natureza: sociedade em transformação. São Paulo: Edusp, 2008. p. $55-70$.

MOURA, R.; OLIVEIRA, S.; PÊGO, B. Escalas da Urbanização Brasileira. Rio de Janeiro: IPEA, 2018. 
NOBRE, C. A.; SAMPAIO, G.; SALAZAR, L. Mudanças climáticas e Amazônia. Ciência e Cultura, Campinas, v. 59, n. 3, p. 22-27, 2007.

ONU - ORGANIZAÇÕES DAS NAÇÕES UNIDAS. World Urbanization Prospects. New York: United Nation, 2014.

PEREIRA, J. C. M. P. A urbanização da Amazônia e o papel das cidades médias na rede urbana regional. In: CARDOSO, J. C. M. (Ed.). O rural e o urbano na Amazônia: diferentes olhares em perspectivas. Belém: EDUFPA, 2006. p. 23-52.

PERZ, S. G. Social Determinants and Land Use Correlates of Agricultural Technology Adoption in a Forest Frontier : A Case Study in the Brazilian Amazon. Human Ecology, v. 31, n. 1, p. 133-165, 2003.

PERZ, S. G.; SKOLE, D. L. Secondary forest expansion in the Brazilian Amazon and the refinement of forest transition theory. Society and Natural Resources, v. 16, p. 277-294, 2003.

PERZ, S. G.; WALKER, R.; CALDAS, M. M. Beyond Population and Environment: Household Demographic Life Cycles and Land Use Allocation Among Small Farms in the Amazon. Human Ecology, v. 34, n. 6, p. 829-849, 2006.

RIBEIRO, R. M. et al. Os processos de urbanização e conversão florestal na Amazônia paraense - um estudo multiescalar. Revista Brasileira de Estudos de População, Belo Horizonte, v. 35, n. 3, p. 1-3, 2019.

RUDEL, T. K. et al. Forest transitions: towards a global understanding of land use change. Global Environmental Change, v. 15, n. 1, p. 23-31, 2005.

RUDEL, T. K.; BATES, D.; MACHINGUIASHI, R. A Tropical Forest Transition? Agricultural Change, Out-migration, and Secondary Forests in the Ecuadorian Amazon. Annals of the Association of American Geographers, v. 92, n. 1, p. 87-102, 2002.

SANTOS, M. A urbanização desigual: a especificidade do fenômeno urbano em países subdesenvolvidos. Petrópolis, Editora Vozes, 2012.

SASSEN, S. Cities are at the center of our environmental future. SAPI EN S. Surveys and Perspectives Integrating Environment and Society, n. 2.3, 2009.

SILVA, J.G. Velhos e novos mitos do rural brasileiro. Estudos Avançados, São Paulo, v.15, n.3, p.37-50, 2003.

SILVA, H.; MONTE-MÓR, R. L. Transições demográficas, transição urbana, urbanização extensiva: um ensaio sobre diálogos possíveis. In: VII Congreso de la Asociación Latinoamericana de Población e XX Encontro Nacional de Estudos Populacionais, 2016, Foz do Iguaçu. Anais...Foz do Iguaçu: ALAP e ABEP, 2016.

SKELDON, R. Population Mobility in Developing Countries. London and New York: Belhaven Press, 1990. 
SPOSITO, M. E. B. A questão cidade-campo: perspectivas a partir da cidade. In: SPOSITO, M. E. B.; WHITACKER, A. (Eds.). Cidade e campo: relações e contradições entre urbano e rural. São Paulo: Expressão Popular, 2006, p.111 - 130.

TANG, J.; WANG, L.; YAO, Z. Spatio-temporal urban landscape change analysis using the Markov chain model and a modified genetic algorithm. International Journal of Remote Sensing, v. 28, n. 15, p. 3255-3271, 2007.

TURNER, B. L.; LAMBIN, E. F.; REENBERG, A. The emergence of land change science for global. Proceedings of the National Academy of Sciences of the United States of America, $v$. 104, n. 52, p. 20666-20672, 2007.

UNFPA - UNITED NATIONS POPULATION FUND. The state of world population 2007: Unleashing the potential of urban growth. New York: UNFPA, 2007.

URIARTE, M.; SCHNEIDER, L.; RUDEL, K. Land transition in the tropics: going beyond the case studies. Biotropica, v. 42, n. 1, p. 1-2, 2010.

URRY, J. Sociology beyond societies: Mobilities for the twenty-first century. Abingdon: Routledge, 2012.

URRY, John. Mobilities. London: Polity, 2007. 335p

VANWEY, L. K.; GUEDES, G. R.; D'ANTONA, A. O. Out-migration and land-use change in agricultural frontiers: insights from Altamira settlement project. Population and Environment, v. 34, p. 44-69, 2011.

VIANA, V. A Amazônia e o interesse nacional. Política Externa, São Paulo, v. 19, n. 4, 2011.

VOSS, P. R. Demography as a Spatial Social Science. Population Research and Policy Review, v. 26, n. 5-6, p. 457-476, 2007.

VOSS, P.; WHITE, K. J. C.; HAMMER, R. B. Explorations in spatial demography. In: KANDEL, W.; BROWN, D. (Eds.). Population Change and Rural Society. Berlin:Springer Science \& Business Media, 2006.

WACHTER, K. W. Spatial demography. PNAS, v. 102, n. 43, p. 15299-15300, 2005.

WALKER, R. et al. Land use and land cover change in forest frontiers: the role of household life cycles. International Regional Science Review, v. 25, n. 2, p. 169-199, 2002.

WANDERLEY, M. N. B. A emergência de uma nova ruralidade nas sociedades modernas avançadas - o " rural " como espaço singular e ator coletivo. Estudos Sociedade e Agricultura, Rio de Janeiro, v. 15, p. 87-145, 2000.

WANDERLEY, M. N. B. Agricultura familiar e campesinato. Estudos Sociedade e Agricultura, Rio de Janeiro, v. 1, p. 42-61, 2003. 
Julia Corrêa Côrtes

$\square$ jcortes@alumni.usp.br

ORCiD: https://orcid.org/0000-0003-1981-8200
Submitted on: $15 / 10 / 2019$

Accepted on: 07/10/2020

2021;24e:01821

\section{Roberto Donato da Silva Júnior}

$\square$ robertod@unicamp.br

ORCiD: https://orcid.org/0000-0002-9101-7048

How to cite: CÔRTES, J. C.; SILVA JÚNIOR, R D. The Interface Between Deforestation and Urbanization in the Brazilian Amazon. Ambiente \& Sociedade. São Paulo, v. 24, p. 1-22, 2021. 


\title{
A Interface entre Desmatamento e Urbanização na Amazônia Brasileira
}

\author{
Julia Corrêa Côrtes \\ Roberto Donato da Silva Júnior
}

São Paulo. Vol. 24, 2021

Artigo Original
Resumo: No atual processo global de urbanização, o urbano torna-se elemento central na reconciliação das questões ambientais. Neste estudo, objetivou-se trabalhar diretrizes para subsidiar uma abordagem metodológica que explicite as relações entre desmatamento e urbanização na Amazônia. Considerando intensa transição urbana na região, realizou-se uma revisão sistemática da literatura para compreender o estado de conhecimento e desafios deste escopo. Destacou-se quatro frentes investigativas com relevantes contribuições, mas que poderiam ser melhor articuladas entre si com ajustes no sistema de análise, reformulação conceitual de urbano e indicadores sensíveis às dinâmicas socioespaciais. Através das abordagens da teoria social das mobilidades e do risco refletiu-se sobre a concepção de uma teoria crítica urbana condizente com a multidimensionalidade e transescalaridade das configurações sociopaisagísticas do tecido urbano. Com a incorporação dos enquadramentos analíticos da demografia espacial, o artigo propõe um conjunto de direcionamentos teórico-metodológicos para abordar a contemporânea interface entre desmatamento e urbanização.

Palavras-chave: Tecido urbano; uso e cobertura da terra; teoria social crítica.

Como citar: CÔRTES, J. C.; SILVA JÚNIOR, R D. A interface entre desmatamento e urbanização na Amazônia brasileira. Ambiente \& Sociedade. São Paulo, v. 24, p. 1-22, 2021.

DOI: http://dx.doi.org/10.1590/1809-4422asoc20190182r1vu2021L1AO 


\title{
La Interfaz entre Deforestación y Urbanización en la Amazonía Brasileña
}

\author{
Julia Corrêa Côrtes \\ Roberto Donato da Silva Júniorv
}

São Paulo. Vol. 24, 2021

Resumen: Lo urbano se vuelve fundamental en la reconciliación de los

Artículo original problemas ambientales dada la actual urbanización global. Este estudio tiene como objetivo buscar un enfoque metodológico que ilumine las relaciones entre la deforestación y urbanización en la Amazonía. Se realizó una revisión sistemática para comprender el estado del conocimiento y los desafíos de este alcance. El análisis destacó cuatro perspectivas de investigación con contribuciones relevantes, que podrían articularse mejor con ajustes en el sistema de análisis, una reformulación conceptual de lo urbano y con variables sensibles a la dinámica socioespacial. Los enfoques de la teoría social de la movilidad y el riesgo apoyan la concepción de una teoría crítica urbana consistente con la multidimensionalidad y transescalaridad de las configuraciones socio-paisajísticas del tejido urbano. Se presenta un marco teórico-metodológico con la perspectiva analítica de la demografía espacial para comprender la interfaz contemporánea entre la deforestación y la urbanización.

Palabras-clave: Tejido urbano; uso y cobertura del suelo; teoría social crítica.

Como citar: CÔRTES, J. C.; SILVA JÚNIOR, R. D. La interfaz entre deforestación y urbanización en la Amazonía brasileña. Ambiente \& Sociedade. São Paulo, v. 24, p. 1-22, 2021.

DOI: http://dx.doi.org/10.1590/1809-4422asoc20190182r1vu2021L1AO 